\title{
A NEW SPECIES OF MICROGONEPLAX CASTRO, 2007 (DECAPODA, BRACHYURA, GONEPLACIDAE) FROM AMBON, INDONESIA
}

\author{
BY \\ TOHRU NARUSE ${ }^{1,3}$ ) and PETER CASTRO ${ }^{2,4}$ ) \\ 1) Transdisciplinary Research Organization for Subtropical and Island Studies, \\ University of the Ryukyus, 870 Uehara, Taketomi, Okinawa 907-1541, Japan \\ 2 ) Biological Sciences Department, California State Polytechnic University, Pomona, \\ California 91768-4032, U.S.A.
}

\begin{abstract}
A new species of the genus Microgoneplax Castro, 2007 (Goneplacidae sensu stricto), is described based on two male specimens from Ambon, Indonesia. The new species differs from its six congeners by the $\mathrm{C}$-shaped and incurved distal part of the male first gonopod and the lanceolate dactylus of its fourth ambulatory leg. All known species of Microgoneplax share an almost identical carapace but have a very different male first gonopod. The male second gonopod is much shorter than the first, setting it apart from most goneplacid genera.
\end{abstract}

\section{RÉSUMÉ}

Une nouvelle espèce de Goneplacidae du genre Microgoneplax Castro, 2007, est décrite à partir de deux spécimens males d'Ambon, Indonésie. La nouvelle espèce diffère de ses cinq congénères par la forme en $\mathrm{C}$, incurvée distalement, de son $\mathrm{G} 1$ et par la forme lancéolée du dactyle de sa quatrième patte ambulatoire. Toutes les espèces connues de Microgoneplax ont une carapace pratiquement identique, mais des G1 très différents. Le G2 de Microgoneplax est beaucoup plus court que le G1, ce qui sépare ce genre de la plupart des autres genres de goneplacides.

\section{INTRODUCTION}

Serène \& Soh (1976) established Singhaplax to accommodate the goneplacids Goneplax ockelmanni Serène, 1971, and G. nipponensis Yokoya, 1933. Castro (2007) revised Goneplacidae, restricted Goneplax Leach, 1814, to four

\footnotetext{
3 ) Corresponding author; e-mail: naruse@lab.u-ryukyu.ac.jp

${ }^{4}$ ) e-mail: pcastro@csupomona.edu 
western Atlantic species and described four new genera for the Indo-West Pacific species previously included in the genus. Singhaplax was redescribed to include Goneplax ockelmanni, G. nipponensis, G. wolffi Serène, 1964, Ommatocarcinus orientalis Tesch, 1918, and four new species, all of which are characterized by their small size, a conspicuous outer orbital tooth but no anterolateral teeth, and a long male second gonopod that is longer, or as long as the male first gonopod. Microgoneplax Castro, 2007, was established for Ommatocarcinus elegans Chen, 1998, and four new species, all of which are nearly identical to the species of Singhaplax except that the male second gonopod is much shorter than the male first gonopod. All 15 species of Singhaplax and Microgoneplax, including S. danielae and M. guinotae described by Takeda \& Komatsu (2010) and a new Microgoneplax species being described here, are morphologically very close to each other and some have been collected from the same stations, suggesting that these species are sympatric. The most obvious difference between these species is the morphology of their respective male first gonopods.

Specimens examined are deposited in the Zoological Reference Collection (ZRC), Raffles Museum of Biodiversity Research, National University of Singapore. Measurements provided are of the carapace length (CL) by the carapace width $(\mathrm{CW})$. The abbreviations $\mathrm{G} 1$ and $\mathrm{G} 2$ are used for the male first and second gonopods, respectively.

\section{TAXONOMY}

GONEPLaCidAe MacLeay, 1838

Microgoneplax Castro, 2007

Microgoneplax danielae n. sp. (figs. 1, 2)

Material examined. - Holotype, male, 3.1 by $6.0 \mathrm{~mm}$, ZRC 2009.0576, Ambon Bay, Indonesia, coarse sand bottom, coll. R. V. "Tirta", 24 Jan. 1975. Paratype, 1 male, 2.6 by $4.7 \mathrm{~mm}, \mathrm{ZRC} 2009.0577$, data same as holotype.

Description. - Carapace (figs. 1a, 2) transversely rectangular, widest between outer orbital angles, CW 1.83-1.93 times CL $(\mathrm{n}=2)$, dorsal surface smooth, longitudinally convex, highest between external orbital angles, regions ill-defined. Front directed ventrally, base not constricted. Supraorbital margins divergent posteriorly, thinly cristate, lined with minute granules, lateral third concave; infraorbital margin thinly cristate, lined with minute granules, inner orbital tooth low, rounded, broadly produced, outer two-thirds convex ventroposteriorly, laterally connected to outer orbital angle. Outer orbital 


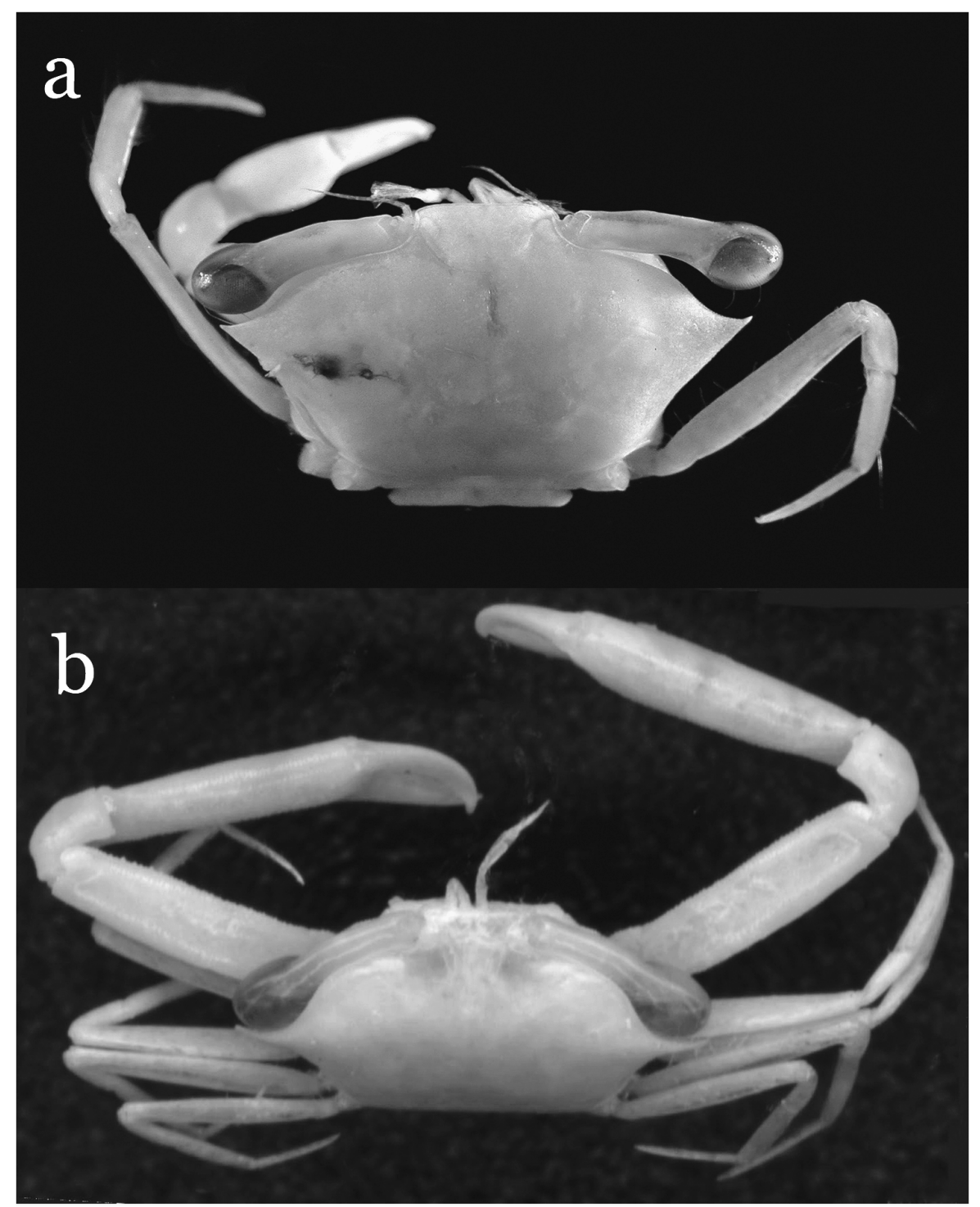

Fig. 1. a, Microgoneplax danielae $\mathrm{n}$. sp., holotype male $(3.1 \times 6.0 \mathrm{~mm}$, ZRC 2009.0576); b, Ommatocarcinus elegans Chen, 1998, holotype male, $(4.3 \times 8.0 \mathrm{~mm}$, SSB III-34).

angle at level of proximal half of carapace, sharp, directed laterally, with tip slightly curved anteriorly, anterolateral tooth absent. Epistome flat, with posterior margin thinly upturned, slightly concave along its breadth.

Antennule developed, long, antennular septum placed behind surfaces of basal antennular segments. Antenna with basal antennal article free in orbital 


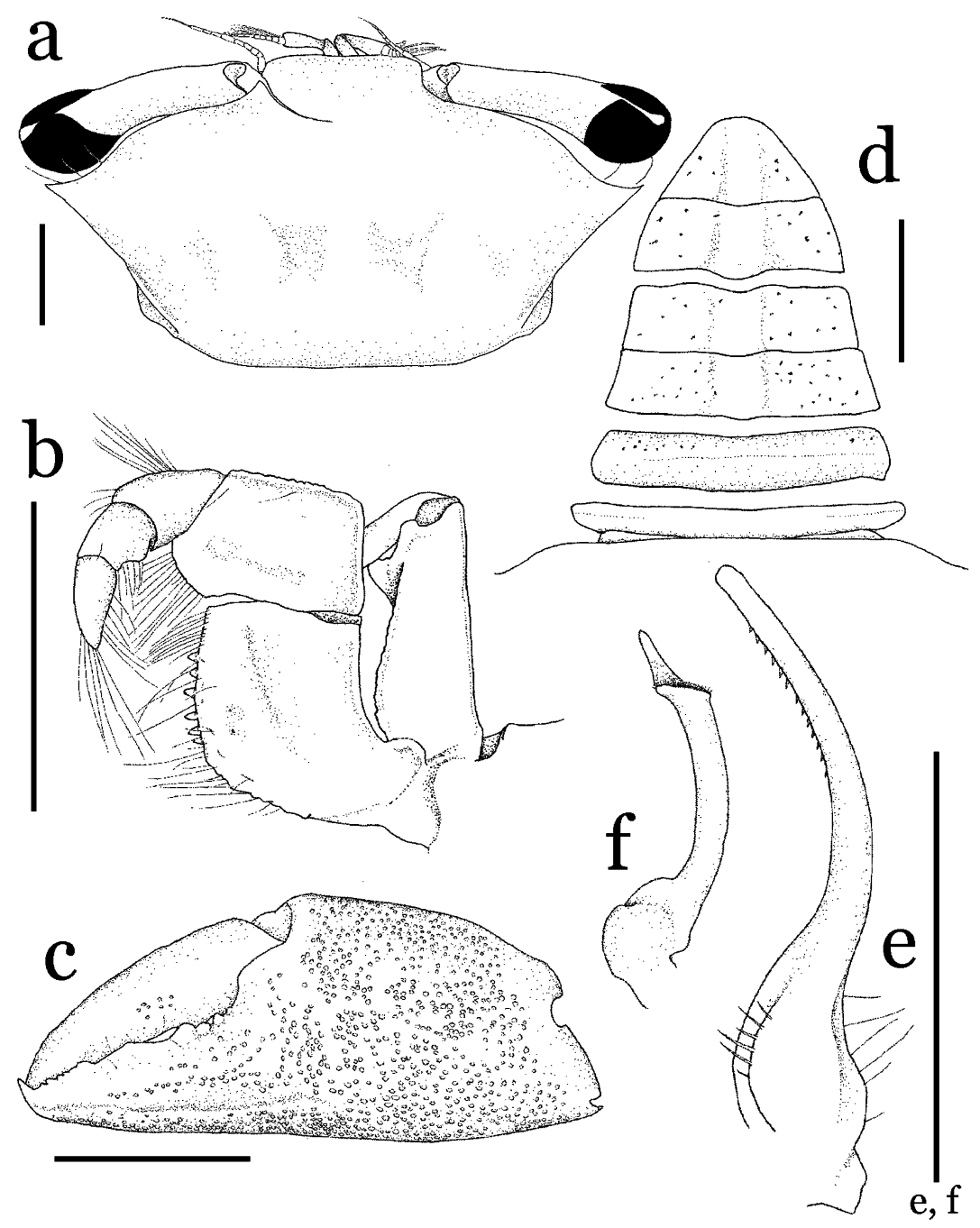

Fig. 2. Microgoneplax danielae n. sp., holotype (male, ZRC 2009.0576). a, carapace; b, left third maxilliped; c, left chela; d, male abdomen, telson, and posterior margin of carapace; e, left G1; f, right G2. Scale bars $=1 \mathrm{~mm}$.

hiatus, not reaching front, flagellum short. Eye (fig. 2a) with long peduncle, tip of eye in frontal view exceeding beyond outer orbital angle by distal quarter of cornea, cornea wider than peduncle. Third maxillipeds (fig. $2 \mathrm{~b}$ ) rectangular, leaving wide gape when closed; ischium rectangular, inner margin dentate, lined with setae, mid-length about twice length of merus; merus with distal inner angle concave; exopod wide, distal end reaching external outer angle of merus, with subdistal triangular tooth on inner margin, flagellum long. 
Male with wide, triangular abdominal cavity, press-button of abdominal locking mechanism thin, high, placed near anterior margin of thoracic sternite 5. Gonopore coxal, penis emerging from sternite 8 near boundary with thoracic sternite 7.

Male holotype with only relatively slender left cheliped (fig. 2c), male paratype with only relatively stout right cheliped. Meri with cristate anterior margins, lined with granules, produced distally, slightly lobe-like. Carpi small, each with rounded outer surface, inner angle pointed as small tubercle. Chelae rather compressed; outer, inner surfaces covered with minute granules, palm slightly longer than immovable finger in male holotype, about two times as long in male paratype; fingers compressed, with low carina from tip of immovable finger to distoventral part of palm, teeth on fingers small in holotype, those of paratype aligned irregulary, proximal quarter of immovable finger concave.

Ambulatory legs (fig. 1a) slender, long. Meri widest on proximal third, no subterminal tooth on anterior margin. Propodus of fourth leg clearly wider than carpus, flat, inner, outer margins densely lined with plumose setae. Dactylus of fourth leg compressed, wide, lanceolate, as long as or slightly longer than propodus; distal half of inner margin, distal two-thirds of outer margin lined with spines; inner margin also lined with long plumose setae.

All abdominal somites, telson freely articulating (fig. 2d), first somite concealed under carapace, third somite widest, convex laterally but far from coxa of fourth ambulatory leg; sixth somite with sockets for sternal condyle on distal outer angles of sternal side. G1 (fig. 2e) slender, distal two-thirds broadly C-shaped, nearly same width along entire length. G2 (fig. 2f) about half length of G1, ventral margin of distal opening fringed with short setae, dorsal margin distally produced to triangular lobe.

Etymology. - We are honoured to name the new species after Prof. Danièle Guinot, whose pioneering work on the Goneplacidae set the standards for present and future work on this challenging group.

Remarks. - Microgoneplax danielae, n. sp. is morphologically most similar to M. elegans (Chen, 1998) and M. prion Castro, 2007, by each sharing a slender and simple G1. The G1 of $M$. danielae, however, differs from those of M. elegans and M. prion by its broadly C-shaped and incurved distal part (sinuous in both M. elegans and M. prion, cf. Chen, 1998, fig. 14 (7); Castro, 2007, fig. 45b). Microgoneplax danielae is also distinct from all its congeners by the lanceolate dactylus of its fourth ambulatory leg. In contrast, the fourth ambulatory legs of all other Microgoneplax species have a thin dactylus (e.g., Castro, 
2007, figs. 42, 46). The dactylus of the fourth ambulatory leg of M. elegans has not been described nor illustrated, however. The holotype of M. elegans is deposited in the Institute of Oceanology, Qingdao, China. The photograph of the holotype of M. elegans (male, SSB III-34, 4.3 by $8.0 \mathrm{~mm}$ ), kindly sent to us by Dr. Li Xinzheng, clearly shows a non-lanceolate dactylus (fig. 1b).

\section{ACKNOWLEDGEMENTS}

We thank Dr. Kasim Moosa who enabled us to examine the present species. Dr. Li Xinzheng (Institute of Oceanology, Qingdao, China) and Nguyen Thanh Son (National University of Singapore) for photographing specimens of Microgoneplax species.

\section{REFERENCES}

CAstro, P., 2007. A reappraisal of the family Goneplacidae MacLeay, 1838 (Crustacea, Decapoda, Brachyura) and revision of the subfamily Goneplacinae, with the description of 10 new genera and 18 new species. Zoosystema, 29: 609-774.

Chen, H., 1998. The Goneplacidae (Crustacea: Brachyura) from Nansha Islands and adjacent waters. In: The Multidisciplinary Oceanographic Expedition Team of Academia Sinica to Nansha Islands (eds.), Studies on marine fauna and flora and biogeography of the Nansha Islands and neighbouring waters, 3: 265-316. (Academia Sinica, Beijing). [In Chinese with English abstract.]

LEACH, W. E., 1814. Crustaceology. In: D. BREWSTER (ed.), The Edinburgh Encyclopaedia, 7: 383-437, pl. 221. (William Blackwood, Edinburgh).

MACLEAY, W. S., 1838. Illustrations of the Annulosa of South Africa; being a portion of the objects of natural history chiefly collected during an expedition into the interior of South Africa, under the direction of Dr. Andrew Smith, in the years 1834, 1835, and 1836; fitted out by the "Cape of Good Hope Association for Exploring Central Africa". In: A. SMITH (ed.), Illustrations of the Zoology of South Africa Investigations: 1-75, pls. 1-4. (Smith, Elder \& Co., London).

SERÈnE, R., 1971. Observations préliminaires sur des Brachyoures nouveaux ou mal connus du Sud-Est Asiatique (Crustacea Decapoda). Bulletin du Muséum national d'Histoire naturelle, Paris, (2) 42 (5) [1970]: 903-918.

SerÈnE, R. \& C. L. SoH, 1976. Brachyura collected during the Thai-Danish Expedition (1966). Research Bulletin Phuket Marine Biological Center, 12: 1-37, fig. 28, pls. I-VII.

YOKOYA, Y., 1933. On the distribution of decapod crustaceans inhabiting the continental shelf around Japan, chiefly based upon the materials collected by S. S. Sôyô-Maru, during the years 1923-1930. Journal of the College of Agriculture, Tokyo Imperial University, 12: $1-226$.

First received 22 March 2009.

Final version accepted 31 May 2009. 